\title{
On the Health Care Luxury Good Hypothesis
}

\author{
Esmaeil Ebadi*
}

\begin{abstract}
A wide range of research has been developed in the empirical literature regarding income and price elasticities of health care expenditure (HCE). The results are mixed, as researchers employ different methodologies and data sources. The benefits of the panel data method, such as greater data variation, less collinearity, and more degrees of freedom, made it attractive among economists. However, the pooled mean group (PMG) method provides robust estimates compared to conventional methods, such as the mean group estimator and dynamic fixed-effects estimator. As such, this paper applies the PMG method to scrutinize the effect of income and price on U.S. health care consumption using a panel of 46 states. The income and price elasticities were found to be 0.85 and -0.48 , respectively, which partially describes the recessionary decline in health care consumption following the Great Recession. In addition, the model reveals that the short-run income elasticity is smaller than the long-run. This confirms that U.S. health care consumption follows the permanent income hypothesis. Consequently, the short-run efficacy of public policies targeting HCE remains limited. The results of this paper suggest reconsidering and adjusting health care policies during a recession so as to avoid probable long-run adverse effects on HCE.
\end{abstract}

JEL classification: E21; I10; C12; C23

Keywords: Consumption; Health care expenditure; Luxury good hypothesis; Permanent income hypothesis; Panel cointegration.

${ }^{*}$ Assistant Professor of Economics, Department of Economics and Finance, Gulf University for Science and Technology, Masjid Al Aqsa Street, Mubarak Al-Abdullah, Kuwait,(ebadi.e@gust.edu.kw). 


\section{Introduction}

The discussion surrounding the income and price elasticities of health care expenditure (HCE) has yielded a broad range of empirical research. The answer to the question of whether a relationship exists between HCE and its determinants plays a crucial role in policy makers' decision-making process. If the relationship is confirmed, the next step involves determining the magnitude of the influences. For instance, a significant and pronounced effect of income on HCE could explain how it behaves during a recessionary period and might bring policy makers' attention to the effect of negative income shocks. While consumers receive services through their health care providers, they might postpone their health care needs (e.g. regular visits or check-ups) in times of economic uncertainty. In addition, consumers would behave differently in the short-run than in the long-run, as consumers build their confidence in the permanency of their income. ${ }^{1}$ Essentially, the fact that U.S. real health care expenditure experienced an alarming decrease following the great recession of 2007-2008 (Figure 1) motivated this paper to scrutinize U.S. health care consumption one more time.

Since the observational studies ${ }^{2}$ apply a variety of methodologies and data sources, the empirical literature provides mixed results regarding health care's necessity and luxury nature. $^{3}$ However, the cointegration approach became a turning point in empirical studies, uncovering the spurious relationship problems that occur due to including nonstationary variables in previous models. ${ }^{4}$ The evolutionary process of the statistical procedure to iden-

\footnotetext{
${ }^{1}$ Permanent income hypothesis (Friedman, 1975).

${ }^{2}$ Studies based on survey or administrative data (Ringel et al., 2002).

${ }^{3}$ The fact that the price a consumer pays for health care service depends on the coinsurance (cost-sharing plan), a deductible, an upper limit on out-of-pocket expenditures, and a premium makes estimating the price elasticity complex, as the quantity of services used influences the price (Ringel et al., 2002). To overcome this issue, one would use data of a specific population to isolate the price effect. For instance, Eichner (1998) studied the insurance claims for those covered through a large employer and examined the out-of-pocket costs effect on medical expenditures (observational). Newhouse et al. (1993) employed the RAND Health Insurance Experiment (HIE) to study how coinsurance rates (as a measurement of price) across plans affected medical expenditures.

${ }^{4}$ See, for instance, Hansen and King (1996), who determined that the standard model of aggregate health care expenditure was not stationary using the data of the 20 members of the Organization for Economic Co-Operation and Development (OECD) and rejected the results of previous studies regarding health care expenditure and income relationship.
} 
Figure 1: Real Personal Per-Capita Health Care Expenditure.

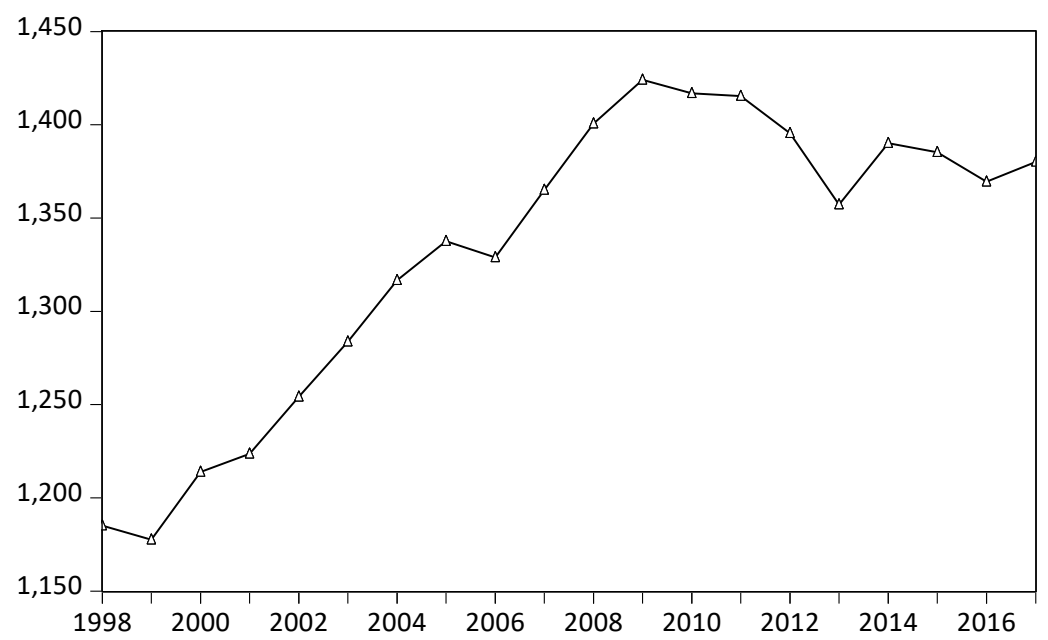

Note: The graph illustrates the median of the real per-capita health care expenditure across states.

tify the causality between health care expenditure and income continued to resolve issues such as nonstationary variables causing spurious regression, omitted variables and endogeneity, and unobserved heterogeneity. ${ }^{5}$

While the approaches of Engel-Granger (1987), Johansen (1988), and Johansen and Juselius (1990) overcome some specification issues, they suffer a considerable shortcoming in their identification. ${ }^{6}$ Specifically, they make some assumptions to include exogenous explanatory variables in the model, ${ }^{7}$ and such assumptions are not reliable. Pesaran and Shin (2001) introduced the autoregressive distributed lag (ARDL) approach, which works even in the presence of endogenous regressors. The ARDL procedure offers an empirical advantage over other asymptotically efficient estimators, such as dynamic ordinary least squares (DOLS), fully modified ordinary least squares (FMOLS), ${ }^{8}$ and maximum likelihood esti-

\footnotetext{
${ }^{5}$ See, for instance, McCoskey and Selden (1998), who applied the panel unit root tests and argued that Hansen and King's (1994) country-by-country analysis is inapplicable to the panel of OECD countries.

${ }^{6}$ See, for instance, Blomqvist and Carter (1997), who applied the Philips-Loretan estimator to overcome the omission of country-specific factors correlated with income for 24 OECD countries. Caporale et al. (2018) followed the well-known Engel-Granger (1987) cointegration approach and found cointegration in only 11 out of 50 U.S. states, providing some evidence that health care represents a luxury in those states. These findings are controversial, as the literature considers the income elasticity to be less than one even after correcting for the biases in health care literature (Costa-Font et al., 2011).

${ }^{7}$ Such as the orthogonality of the errors and the variable-ordering assumptions (Romer and Romer, 2009).

${ }^{8}$ Using the data for 50 states in the U.S., Rettenmaier and Wang (2007) applied this method and determined that health care represents a luxury in almost all states. Interestingly, when Clemente et al.
} 
mation (MLE), because it represents an optimal estimator (Panopoulou and Pittis, 2004). However, the ARDL method sometimes provides economically implausible coefficients for specific groups due to too much aggregation, sample-specific omitted variables, or measurement errors correlated with the regressors. ${ }^{9}$

The advantages of the panel data method, such as greater data variation, less collinearity, and more degrees of freedom, have attracted economists in the recent literature. While some studies have focused on testing the cointegration relationship using different panel unit root tests, ${ }^{10}$ others have provided estimates for the income elasticity together with cointegration tests. ${ }^{11}$ However, the conventional methods occupy two polar extremes in their assumptions: They either assume different intercepts and slopes for all groups (pooled ordinary least square) or different intercepts and the same slopes for all groups (fixed-effects and randomeffects). ${ }^{12}$ Unlike the conventional panel approaches, Pesaran et al. (1999) introduced an intermediate approach and considered the economic convergence to construct the pooled mean group (PMG) estimator. This method allows for different coefficients in the short-run (heterogeneity) and identical coefficients in the long-run (homogeneity). While the approach assumptions appear more realistic than two polar extremes, it bears empirical power over conventional methods, such as the mean group estimator (MG) and dynamic fixed-effects estimator, as it is robust to lag orders, lag-selection criteria, and outliers. Therefore, for the first time in the literature, I employ the PMG method to estimate the health care consumption function in the U.S. using a panel of 46 states over a period from 1998 to 2017.

The remainder of this paper is organized as follows: Section 2 discusses the model and methodology. Section 3 provides empirical results. Finally, section 4 summarizes the conclusions of this study.

(2004) employed the method for a sample of countries including the U.S., they also identified health care as a luxury for the U.S.

${ }^{9}$ Pesaran et al. (1999).

${ }^{10}$ See, for instance, McCoskey and Selden (1998), Gerdtham and Lothgren (2000), MacDonal and Hopkins (2002), and Carrion-i-Silvestre (2005).

${ }^{11}$ See, for instance, Rettenmaier and Wang (2006), Moscone and Tosetti (2010).

${ }^{12}$ See, for instance, Moscone and Tosetti (2010), who employed the conventional methods and identified income elasticity to reside in a range between 0.36 and 0.96 . 


\section{Model and Methodology}

To estimate the income and price elasticities of health care consumption, I follow a standard consumption function of the Davidson et al. (1978) ${ }^{13}$ type for a sample of 46 U.S. states over the 1998-2017 period. ${ }^{14}$ I assume that the long-run consumption function is as follows:

$$
\begin{gathered}
h c_{i t}=\theta_{0 i}+\theta_{1 i} y_{i t}^{d}+\theta_{2 i} \pi_{i t}+v_{i t} \\
i=1,2, \ldots, N, t=1,2, \ldots, T
\end{gathered}
$$

Where $h c_{i t}$ is the logarithm of real per-capita health care expenditure, $y_{i t}^{d}$ is the logarithm of real per-capita disposable income, and $\pi_{i t}$ is the logarithm of the medical care price index (the rate of inflation) as a proxy for different wealth effects. I postulate that disposable income increases $\mathrm{HCE}\left(\theta_{0 i}>0\right)$ and inflation affects it adversely $\left(\theta_{2 i}<0\right)$. To measure real per-capita disposable income, I deflate per-capita disposable income using the consumer price index for all items. ${ }^{15}$ Regarding health care expenditure, I deflate personal per-capita health care expenditure by the medical care price index. I assume that each of these variables are $I(1)$, which makes $v_{i t}$ an $I(0)$ for all $i .{ }^{16}$ I impose a maximum lag of one to obtain the autoregressive distributed lag (ARDL) $(1,1,1)$ equation as follows:

$$
h c_{i t}=\mu_{i}+\delta_{10 i} y_{i t}^{d}+\delta_{11 i} y_{i, t-1}^{d}+\delta_{20 i} \pi_{i t}+\delta_{21 i} \pi_{i, t-1}+\lambda_{i} h c_{i, t-1}+\varepsilon_{i t}
$$

\footnotetext{
${ }^{13}$ In the literature, studies consider the income, the proportion of the population aged 65 and older, life expectancy at birth, and healthcare research and development (R\&D) expenditure and utilize long time series data. However, I employ the standard consumption function including the medical care price index to examine the income and different wealth effects on health care consumption.

${ }^{14}$ See the Appendix for the list of states used in the study.

${ }^{15}$ Data was collected from the Federal Reserve of Saint Luis and the U.S. Bureau of Labor Statistics.

${ }^{16}$ I apply Kao's (1999) residual-based test for cointegration in the panel data, which possesses a better size and power properties, and reject the null hypothesis of no cointegration (the t-statistic and p-value are -4.41 and 0.00 , respectively).
} 
Therefore, the error correction equation is

$$
\Delta h c_{i t}=\phi_{i}\left(h c_{i, t-1}-\theta_{0 i}-\theta_{1 i} y_{i t}^{d}-\theta_{2 i} \pi_{i t}\right)-\delta_{11 i} \Delta y_{i t}^{d}-\delta_{21 i} \Delta \pi_{i t}+\varepsilon_{i t}
$$

where

$$
\theta_{0 i}=\frac{\mu_{i}}{1-\lambda_{i}}, \theta_{1 i}=\frac{\delta_{10 i}+\delta_{11 i}}{1-\lambda_{i}}, \theta_{2 i}=\frac{\delta_{20 i}+\delta_{21 i}}{1-\lambda_{i}}, \phi_{i}=-\left(1-\lambda_{i}\right)
$$

It is worth mentioning that previous studies avoided including the price of health care in the model, as the quantity of a service affects the price, causing endogeneity issues. Since the ARDL approach performs well despite including endogenous regressors, the PMG method uses the maximum likelihood (ML $)^{17}$ estimations of the ARDL model to obtain longrun coefficients considering the homogeneity restrictions. In addition, the method employs the average across the groups to obtain group-wide mean estimates of the error correction coefficients and the short-run model parameters.

Pesaran et al. (1999) provided the computational procedure written in the GAUSS platform. I modified the program and followed the computation process, assuming maximum lags of one to estimate the model. ${ }^{18}$ Primarily, I utilized the Bayesian information criterion (SBC) to determine the optimal lags. However, to check the model's robustness, I repeated the estimation procedure using the Akaike information criterion (AIC) as well. In addition, I imposed maximum lags of two and removed the outliers to investigate each change's effect. Finally, for the sake of curiosity, I removed nine rich states from the model to examine the probable changes in coefficients.

\footnotetext{
${ }^{17}$ Pesaran et al. (1999) chose the ML method over the ordinary least square (OLS) due to the latter's shortcomings in the estimation procedure.

${ }^{18}$ For more information, see Ebadi (2021).
} 


\section{Empirical Results}

Table 1 illustrates state-specific estimates and diagnostic results based on ARDL specifications selected by the schwarz criterion (SBC). The results of the serial correlation test (LM residual test) reveal that only three states (New Hampshire, North Dakota, and Rhode Island) experience serial correlation. This assures that the model performs well in this manner. The functional form test (Ramsey Reset test) confirms that the model possesses a well-defined functional form, as only three states (Arizona, Arkansas, and Florida) indicate evidence of miss-specification. Finally, the model provides no evidence of non-normality except in two states (Minnesota and Utah).

The income elasticity of health care consumption was found to be 0.85 (Table 2). ${ }^{19}$ The price elasticity of health care equals approximately -0.48. In addition, the speed of adjustment confirms the existence of a cointegration relationship in the model, as the coefficient is negative and significant (-0.14). ${ }^{20}$ As such, it takes approximately 4.5 years for an existing disequilibrium to be reduced by $50 \%$ (half-life disequilibrium). While the Hausman test indicates the equality of the PMG and MG estimations, the result changes when I remove the outliers. Pesaran et al. (1999) confirmed that, when the standard errors are large, the Hausman test is misleading.

To check the model's robustness, I employed AIC lag-selection criteria, removed outliers, applied predetermined lag orders, and considered the maximum lags of two in the model. ${ }^{21}$ In response, I found that the coefficients (Table 2) responded slightly to the changes. For the sake of empirical comparison, I applied the DOLS, FMOLS, and GMM methods to estimate the model using the same data set. The results confirm that empirically the PMG performs better than other methods and provides economically plausible coefficients (Table 2).

The results explain the alarming decrease in real health care consumption, which occurred

\footnotetext{
${ }^{19}$ After correcting for studies' biases, Costa-Font and Gemmill (2011) identified a range between 0.4 and 0.8 for income elasticity.

${ }^{20}$ Pesaran et al. (1996).

${ }^{21}$ Results are available upon request.
} 
Figure 2: U.S. Real Per-Capita Health Care Expenditure.

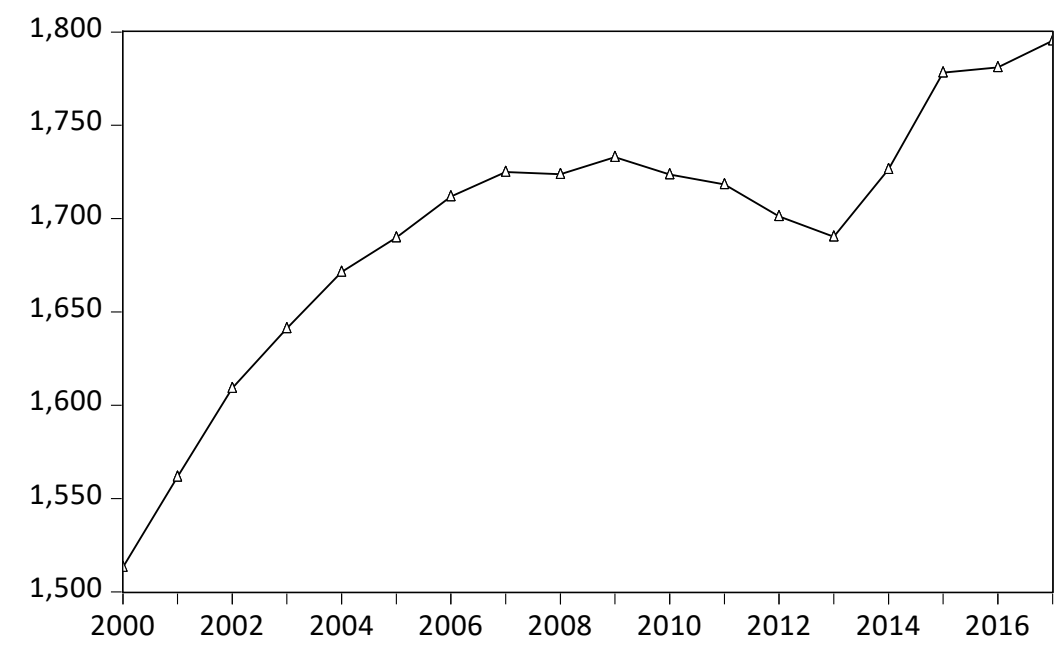

Note: Data extracted from the Federal Reserve of St. Louis.

following the Great Recession and its slow adjustment. Considering the income and price elasticities $(0.85,-0.48$, respectively), I postulate that the decline resulted from the negative income shock and negative wealth effects. Roughly speaking, a 1\% negative income shock combined with a negative wealth effect decreases HCE by $1.3 \%$. This indicates that, while HCE represents a necessity, the wealth effect makes it more vulnerable during a recession. It is worth noting that U.S. real health care per capita experienced an average decline of $\$ 10$ between 2010 and 2013 (Figure 2). ${ }^{22}$

Although this paper's core objective is to scrutinize how income and wealth influence health care consumption, the results offer evidence that health care consumption follows the permanent income hypothesis (PIH), as the short-run income elasticity (0.12) is far less than the long-run. In other words, public policies' short-run efficacy in resolving health care market disequilibria is limited, as it takes time for consumers to build confidence regarding their income's permanency. ${ }^{23}$ Interestingly, even removing the nine rich states (Maryland, Connecticut, Alaska, Virginia, New Jersey, Massachusetts, New Hampshire, California, and

\footnotetext{
${ }^{22}$ I deflated U.S. health care per capita using the medical care CPI and observed the fact.

${ }^{23}$ Caporale et al. (2018) distinguished between short- and long-run income elasticity and determined that income elasticity is lower in the short-run. However, the findings appear problematic, as the common belief in the literature is that health care represents a necessity; the authors missed the point that their findings might confirm the PIH for health care expenditure.
} 
Washington) ${ }^{24}$ from the panel did not change HCE to a luxury (Table 3), which could offer further evidence of HCE being a necessity rather than a luxury. Moreover, the model with a panel of 37 states remains robust to the changes applied to check its robustness with a panel of 46 states.

Finally, a recent study ${ }^{25}$ shows that due to the Covid-19 recession "nearly one in five U.S. adults forgoing some healthcare in the prior 12 months due to the cost and many Americans are cutting back on household spending to pay for the care that they currently are receiving. The results confirm that income is alongside wealth are the most important determinants of health care expenditure especially during business cycles.

The study provides some evidence in support of the necessity than luxury nature of health care expenditure as "about one in eight adults say they cut back their spending on food $(12 \%)$ and over-the-counter drugs (11\%) to pay for healthcare or medicine." However, "the proportion doing this rises to about $1 / 4$ of those in households earning less than $\$ 24,000$ annually. Thus, we would expect that low-income families suffer disproportionately in the COVID-era as $21 \%$ of those from low-income households have had to reduce spending on utilities due to the cost of care."

\section{Conclusion and Policy Implications}

Since the empirical literature employs different methods and data sets, it provides mixed results regarding the income and price elasticity of health care consumption in the U.S. The evolutionary process of the empirical studies continued, and cointegration resided at the center of the spectrum, as it uncovered spurious regression. While some studies rejected the long-run relationship between health care consumption and income, other studies confirm the existence of cointegration considering the panel unit root tests instead of country-bycountry tests. Since the PMG method performs better than the conventional methods, and

\footnotetext{
${ }^{24}$ The rank is based on the wealthiest U.S. states according to median household income reported by the Census Bureau's American Community Survey (Blystone, 2019).

${ }^{25}$ West Health-Gallup Healthcare Study (February 15, 2021, n=3,753.)
} 
it is robust to outliers, lag-selection criteria, and lag order, this paper, for the first time in the literature, applies this method to estimate health care consumption in the U.S. using a set of data for 46 states over a period from 1998 to 2017.

After correcting for the studies' biases, the empirical literature identified a range between 0.40 and 0.80 for HCE's income elasticity. However, the wealth effect remained uncovered in the empirical studies. Previous studies avoided including the price of health care, as the quantity of a service affects the price and makes estimating price elasticity complex. However, in this paper, I apply a method that works despite the presence of endogenous variables in the model.

The findings reveal that the income elasticity of health care consumption equals roughly 0.85, and the price (as a proxy for different wealth effects) elasticity reaches approximately -0.48. The coefficients are robust to the outliers, lag order, and lag-selection criteria. The speed of adjustment confirms a slow adjustment of HCE toward its steady state, and it takes approximately 4.5 years for an existing disequilibrium to be reduced by $50 \%$. In addition, the negative and significant speed of adjustment coefficient illustrates cointegration among the variables in the model.

Although this paper's core objective is to investigate health care consumption behavior, the short-run income elasticity (0.12) confirms that health care consumption follows the permanent income hypothesis (PIH). In other words, the short-run efficacy of public policies targeting health care remains limited in the short-run rather than in the long-run. Moreover, upon removing the rich states, I found that HCE remains a necessity rather than a luxury, and the results are still robust to lag orders, lag-selection criteria, and outliers.

I doubt that, over the period of this study (1998-2017), other variables such as the proportion of the population aged 65 and older, life expectancy at birth, and healthcare research and development $(\mathrm{R} \& \mathrm{D})$ expenditure could describe the recessionary decline in health care consumption that occurred after 2008. However, the findings regarding how income and wealth affect U.S. health care consumption combined with the slow speed of 
adjustment explains the reason behind the alarming decrease in HCE and its slow adjustment following the Great Recession. The results of this paper suggest reconsidering and adjusting health care policies during a recession so as to avoid probable long-run adverse effects on HCE.

\section{Appendix}

\section{List of States in the study}

Alabama, Alaska, Arizona, Arkansas, California, Colorado, Connecticut, Delaware, Florida, Georgia, Idaho, Illinois, Iowa, Kansas, Kentucky, Louisiana, Maine, Maryland, Massachusetts, Michigan, Minnesota, Mississippi, Montana, Nebraska, Nevada, New Hampshire, New Jersey, New Mexico, New York, North Carolina, North Dakota, Ohio, Oklahoma, Oregon, Pennsylvania, Rhode Island, South Carolina, South Dakota, Texas, Utah, Vermont, Virginia, Washington, West Virginia, Wisconsin, Wyoming.

\section{References}

Blomqvist, A.G., Carter, R.A.L. (1997), Is health care really a luxury? Journal of Health Economics, 16, 207-229.

Blystone, D. (2019), Top 10 Richest U.S. States, Retrieved from http://aozhoupedia.com/10wealthiest-states-united-states.html, Accessed 10 April 2020.

Caporale, G. M., Cunado, J., Gil-Alana, L. A., and Gupta, R. (2018), The relationship between healthcare expenditure and disposable personal income in the US states: a fractional integration and cointegration analysis, Empirical Economics, 55, 913-935.

Carrion-i-Silvestre, J. L. (2005), Health care expenditure and GDP: Are they broken stationary?, Journal of Health Economics, 24, 839-854.

Clemente, J., Marcuello, C., Motanes, A., and Pueyo, F. (2003), On the international stability of health care expenditure functions: are government and private functions similar?, Journal of Health Economics, 23, 589-613.

Costa-Font, J, Gemmill, M., and Rubert, G., (2011), Biases in the healthcare luxury good hypothesis? :a meta-regression analysis, Journal of the Royal Statistical Society Series A (Statistics in Society), 174, 95-107.

Davidson, J. E. H., Hendry, D. F., Srba, F., and Yeo, S. (1978), Econometric Modelling of the Aggregate Time-Series Relationship Between Consumers' Expenditure and Income in the United Kingdom, Economic Journal, 88, 661-692. 
Ebadi, E. (2021), Does the Turbulence of the Stock Market Terrify Consumers? Evidence from a Panel of U.S. States Using Pooled Mean Group Estimation, EERI Research Paper Series EERI RP 2021/06, Economics and Econometrics Research Institute (EERI), Brussels.

Economic Research Division, Federal Reserve of St. Louis (2020), Health Expenditures Per Capita Data, Retrieved from https://fred.stlouisfed.org/series/HLTHSCPCHCSA, Accessed 10 April 2020.

Eichner, M. J. (1998), The demand for medical care: What people pay does matter, American Economic Review, 88, 117-121.

Engle R.F., Granger C.W.J. (1987), Co-integration and error correction: representation, estimation and testing, Econometrica, 55, 251-276.

Friedman, M. (1957), A Theory of the Consumption Function, Princeton, NJ: Princeton University Press.

Gerdtham, U.-G., Lothgren, M. (2000), On stationarity and cointegration of international health expenditure and GDP, Journal of Health Economics, 19, 461-475.

Hansen, P., King, A. (1996), The determinants of health expenditure: a cointegration approach. Journal of Health Economics, 15, 127-137.

Johansen, S. (1988), Statistical analysis of cointegration vectors, Journal of Economic Dynamics and Control, 12, 231-254.

Johansen, S., Juselius, K. (1990), Maximum likelihood estimation and inferences on cointegration with application to the demand for money, Oxford Bulletin of Economics and Statistics, 52, 169-210.

Kao, C. (1999), Spurious regression and residual-based tests for cointegration in panel data, Journal of Econometrics, 90, 1-44.

MacDonald, G. and Hopkins, S. (2002), Unit root properties of OECD health care expenditure and GDP data, Health Economics, 11, 371-376.

McCoskey, S. and Selden, T. (1998), Health care expenditures and GDP: panel data unit root test results, Journal of Health Economics, 17, 369-376.

Moscone, F., Tosetti, E. (2010), Health expenditure and income in the United States, Health Economics, 19, 1385-1403.

Newhouse, J. P., and the Insurance Experiment Group (1993), Free For All? Lessons from the Health Insurance Experiment, Harvard University Press, Cambridge.

Panopoulou E. and Pittis N. (2004), A Comparison of Autoregressive Distributed Lag and Dynamic OLS Cointegration Estimators in the Case of a Serially Correlated Cointegration Error, Econometrics Journal, 7, 585-617. 
Pesaran, M. H. and Shin, Y. (1999), An Autoregressive Distributed Lag Modeling Approach to Cointegration Analysis, Econometrics and Economic Theory in the 20th Century, Chapter 11, The Ragnar Frisch Centennial Symposium Cambridge University Press.

Pesaran, M. H., Shin, Y., and Smith, R. J. (1999), Pooled mean group estimation of dynamic heterogeneous panels, Journal of the American Statistical Association, 94, 621-634.

Pesaran, M. H., Shin, Y., and Smith, R. J. (1996), Testing for the Existence of a Longrun Relationship, Cambridge Working Papers in Economics 9622, Faculty of Economics, University of Cambridge.

Rettenmaier, A. J. and Wang, Z. (2006), A note on cointegration of health expenditures and income, Health Economics, 16, 559-578.

Ringel, J. S., Hosek, S. D., Vollaard, B.A., and Mahnovski, S. (2002), The Elasticity of Demand for Health Care A Review of the Literature and Its Application to the Military Health System, Santa Monica, CA: RAND Corporation.

Romer, C. D. and Romer, D. H. (2009), The Macroeconomic Effects of Tax Changes: Estimates Based on a New Measure of Fiscal Shocks, American Economic Review, 100, 763-801.

U.S. Bureau of Labor Statistics (2020), Consumer Price Index (Medical Care) Data, Retrieved form https://data.bls.gov/PDQWeb/cu, Accessed 10 April 2020.

West Health-Gallup Healthcare Study (February 15, 2021),15-21. 
Table 1: State-Specific Estimates and Diagnostic Results (ARDL).

\begin{tabular}{|c|c|c|c|c|c|c|c|c|}
\hline State & $\phi$ & $\theta_{1}$ & $\theta_{2}$ & $\chi_{S C}^{2}$ & $\chi_{F E}^{2}$ & $\chi_{N O}^{2}$ & $\chi_{H E}^{2}$ & $\bar{R}^{2}$ \\
\hline $\mathrm{AL}$ & $\begin{array}{r}-0.235 \\
(0.139)\end{array}$ & $\begin{array}{r}1.034 \\
(1.032)\end{array}$ & $\begin{array}{c}-0.292 \\
(0.409)\end{array}$ & 0.05 & 0.17 & 1.31 & 0.00 & 0.62 \\
\hline $\mathrm{AK}$ & $\begin{array}{r}-0.083 \\
(0.109)\end{array}$ & $\begin{array}{r}2.990 \\
(4.445)\end{array}$ & $\begin{array}{l}-1.950 \\
(3.121)\end{array}$ & 1.38 & 0.10 & 0.81 & 0.00 & 0.72 \\
\hline $\mathrm{AZ}$ & $\begin{array}{r}-0.183 \\
(0.088)\end{array}$ & $\begin{array}{r}0.879 \\
(0.697)\end{array}$ & $\begin{array}{l}-0.400 \\
(0.260)\end{array}$ & 0.75 & 6.06 & 0.28 & 0.00 & 0.34 \\
\hline $\mathrm{AR}$ & $\begin{array}{r}-0.160 \\
(0.112)\end{array}$ & $\begin{array}{r}3.150 \\
(2.109)\end{array}$ & $\begin{array}{l}-1.423 \\
(0.924)\end{array}$ & 0.96 & 8.52 & 0.05 & 0.00 & 0.52 \\
\hline $\mathrm{CA}$ & $\begin{array}{r}-0.616 \\
(0.186)\end{array}$ & $\begin{array}{r}0.112 \\
(0.157)\end{array}$ & $\begin{array}{r}0.359 \\
(0.057)\end{array}$ & 0.41 & 0.51 & 0.66 & 0.00 & 0.46 \\
\hline $\mathrm{CO}$ & $\begin{array}{r}-0.110 \\
(0.071)\end{array}$ & $\begin{array}{r}7.977 \\
(5.734)\end{array}$ & $\begin{array}{l}-1.832 \\
(1.421)\end{array}$ & 1.96 & 0.01 & 0.35 & 0.00 & 0.78 \\
\hline $\mathrm{CT}$ & $\begin{array}{r}-1.000 \\
\text { NA }\end{array}$ & $\begin{array}{r}-0.311 \\
(0.104)\end{array}$ & $\begin{array}{r}0.124 \\
(0.033)\end{array}$ & 0.04 & 0.05 & 0.32 & 0.00 & 0.44 \\
\hline $\mathrm{DE}$ & $\begin{array}{r}-0.412 \\
(0.103)\end{array}$ & $\begin{array}{r}-0.030 \\
(0.215)\end{array}$ & $\begin{array}{r}0.421 \\
(0.052)\end{array}$ & 0.13 & 0.38 & 2.86 & 0.00 & 0.46 \\
\hline FL & $\begin{array}{r}-0.035 \\
(0.155)\end{array}$ & $\begin{array}{r}4.055 \\
(18.726)\end{array}$ & $\begin{array}{l}-1.494 \\
(6.563)\end{array}$ & 0.10 & 6.95 & 0.73 & 0.00 & 0.40 \\
\hline GA & $\begin{array}{r}-0.157 \\
(0.089)\end{array}$ & $\begin{array}{r}0.629 \\
(1.917)\end{array}$ & $\begin{array}{r}0.172 \\
(0.476)\end{array}$ & 0.55 & 0.18 & 5.18 & 0.00 & 0.63 \\
\hline ID & $\begin{array}{r}-0.192 \\
(0.138)\end{array}$ & $\begin{array}{r}1.394 \\
(0.751)\end{array}$ & $\begin{array}{l}-0.356 \\
(0.201)\end{array}$ & 1.71 & 0.02 & 0.17 & 0.00 & 0.68 \\
\hline IL & $\begin{array}{r}-0.434 \\
(0.110)\end{array}$ & $\begin{array}{r}0.343 \\
(0.177)\end{array}$ & $\begin{array}{r}0.288 \\
(0.073)\end{array}$ & 0.04 & 0.27 & 1.49 & 0.00 & 0.68 \\
\hline IA & $\begin{array}{r}-0.365 \\
(0.202)\end{array}$ & $\begin{array}{r}0.457 \\
(0.394)\end{array}$ & $\begin{array}{r}0.029 \\
(0.235)\end{array}$ & 0.18 & 0.42 & 1.26 & 0.00 & 0.50 \\
\hline $\mathrm{KS}$ & $\begin{array}{r}-0.174 \\
(0.089)\end{array}$ & $\begin{array}{l}-0.400 \\
(0.755)\end{array}$ & $\begin{array}{r}0.496 \\
(0.426)\end{array}$ & 0.01 & 0.82 & 1.32 & 0.00 & 0.78 \\
\hline $\mathrm{KY}$ & $\begin{array}{c}-0.393 \\
(0.156)\end{array}$ & $\begin{array}{r}1.742 \\
(0.844)\end{array}$ & $\begin{array}{l}-0.458 \\
(0.207)\end{array}$ & 0.42 & 2.50 & 1.09 & 0.00 & 0.73 \\
\hline LA & $\begin{array}{r}-0.354 \\
(0.209)\end{array}$ & $\begin{array}{r}0.513 \\
(0.401)\end{array}$ & $\begin{array}{l}-0.076 \\
(0.237)\end{array}$ & 1.53 & 0.00 & 0.12 & 0.00 & 0.01 \\
\hline $\mathrm{ME}$ & $\begin{array}{r}-0.322 \\
(0.188)\end{array}$ & $\begin{array}{r}1.032 \\
(0.913)\end{array}$ & $\begin{array}{l}-0.022 \\
(0.280)\end{array}$ & 5.29 & 0.07 & 0.74 & 0.00 & 0.46 \\
\hline MD & $\begin{array}{r}-0.535 \\
(0.118)\end{array}$ & $\begin{array}{r}0.072 \\
(0.241)\end{array}$ & $\begin{array}{r}0.214 \\
(0.078)\end{array}$ & 0.88 & 0.87 & 1.01 & 0.00 & 0.53 \\
\hline MA & $\begin{array}{r}-0.310 \\
(0.207)\end{array}$ & $\begin{array}{l}-0.525 \\
(0.499)\end{array}$ & $\begin{array}{r}0.274 \\
(0.184)\end{array}$ & 1.03 & 2.65 & 1.46 & 0.00 & -0.03 \\
\hline MI & $\begin{array}{r}-0.308 \\
(0.089)\end{array}$ & $\begin{array}{l}-0.096 \\
(0.250)\end{array}$ & $\begin{array}{r}0.405 \\
(0.106)\end{array}$ & 0.11 & 0.16 & 1.01 & 0.00 & 0.76 \\
\hline $\mathrm{MN}$ & $\begin{array}{r}-0.234 \\
(0.155)\end{array}$ & $\begin{array}{r}0.526 \\
(0.694)\end{array}$ & $\begin{array}{l}-0.372 \\
(0.223)\end{array}$ & 0.00 & 2.28 & 6.58 & 0.00 & 0.26 \\
\hline MS & $\begin{array}{r}-0.113 \\
(0.048)\end{array}$ & $\begin{array}{r}-0.439 \\
(0.353)\end{array}$ & $\begin{array}{r}0.416 \\
(0.440)\end{array}$ & 0.12 & 1.71 & 5.16 & 0.00 & 0.75 \\
\hline $\mathrm{MT}$ & $\begin{array}{r}-0.255 \\
(0.158)\end{array}$ & $\begin{array}{r}0.203 \\
(0.615)\end{array}$ & $\begin{array}{r}0.124 \\
(0.261)\end{array}$ & 1.02 & 2.89 & 0.30 & 0.00 & 0.59 \\
\hline
\end{tabular}

${ }^{a}$ Standard errors are in parentheses. 
Table 1: (continued) State-Specific Estimates and Diagnostic Results.

\begin{tabular}{|c|c|c|c|c|c|c|c|c|}
\hline State & $\phi$ & $\theta_{1}$ & $\theta_{2}$ & $\chi_{S C}^{2}$ & $\chi_{F E}^{2}$ & $\chi_{N O}^{2}$ & $\chi_{H E}^{2}$ & $\bar{R}^{2}$ \\
\hline $\mathrm{NE}$ & $\begin{array}{r}-0.337 \\
(0.254)\end{array}$ & $\begin{array}{r}-0.157 \\
(0.548)\end{array}$ & $\begin{array}{r}0.430 \\
(0.405)\end{array}$ & 1.96 & 0.19 & 0.86 & 0.00 & 0.32 \\
\hline NV & $\begin{array}{r}-0.169 \\
(0.130)\end{array}$ & $\begin{array}{r}0.708 \\
(0.823)\end{array}$ & $\begin{array}{r}-0.046 \\
(0.240)\end{array}$ & 0.09 & 5.38 & 0.77 & 0.00 & 0.26 \\
\hline $\mathrm{NH}$ & $\begin{array}{r}-0.596 \\
(0.210)\end{array}$ & $\begin{array}{r}-0.571 \\
(0.339)\end{array}$ & $\begin{array}{r}0.668 \\
(0.080)\end{array}$ & 10.50 & 0.43 & 0.93 & 0.00 & 0.23 \\
\hline NJ & $\begin{array}{r}-0.620 \\
(0.144)\end{array}$ & $\begin{array}{r}0.480 \\
(0.167)\end{array}$ & $\begin{array}{r}0.109 \\
(0.049)\end{array}$ & 0.07 & 2.97 & 1.27 & 0.00 & 0.58 \\
\hline NM & $\begin{array}{r}-0.445 \\
(0.188)\end{array}$ & $\begin{array}{r}2.264 \\
(0.819)\end{array}$ & $\begin{array}{r}-0.481 \\
(0.276)\end{array}$ & 0.24 & 0.66 & 1.64 & 0.00 & 0.43 \\
\hline NY & $\begin{array}{r}-0.179 \\
(0.139)\end{array}$ & $\begin{array}{r}0.241 \\
(0.881)\end{array}$ & $\begin{array}{r}-0.043 \\
(0.457)\end{array}$ & 5.01 & 0.17 & 1.34 & 0.00 & 0.33 \\
\hline $\mathrm{NC}$ & $\begin{array}{r}-0.094 \\
(0.087)\end{array}$ & $\begin{array}{r}0.271 \\
(1.612)\end{array}$ & $\begin{array}{r}-0.418 \\
(0.554)\end{array}$ & 1.26 & 4.88 & 0.41 & 0.00 & 0.70 \\
\hline ND & $\begin{array}{r}-1.000 \\
\text { NA }\end{array}$ & $\begin{array}{r}-0.107 \\
(0.078)\end{array}$ & $\begin{array}{r}0.250 \\
(0.057)\end{array}$ & 32.30 & 0.34 & 0.30 & 0.00 & 0.14 \\
\hline $\mathrm{OH}$ & $\begin{array}{r}0.018 \\
(0.098)\end{array}$ & $\begin{array}{r}-6.861 \\
(38.994)\end{array}$ & $\begin{array}{r}5.079 \\
(26.461)\end{array}$ & 0.01 & 0.03 & 0.18 & 0.00 & 0.54 \\
\hline OK & $\begin{array}{r}-0.041 \\
(0.139)\end{array}$ & $\begin{array}{r}2.474 \\
(7.218)\end{array}$ & $\begin{array}{r}-2.436 \\
(7.916)\end{array}$ & 0.99 & 5.88 & 0.12 & 0.00 & 0.35 \\
\hline OR & $\begin{array}{r}-0.109 \\
(0.118)\end{array}$ & $\begin{array}{r}2.446 \\
(2.315)\end{array}$ & $\begin{array}{l}-0.751 \\
(0.763)\end{array}$ & 0.28 & 0.12 & 1.36 & 0.00 & 0.61 \\
\hline $\mathrm{PA}$ & $\begin{array}{r}-0.019 \\
(0.080)\end{array}$ & $\begin{array}{r}18.239 \\
(79.177)\end{array}$ & $\begin{array}{r}6.063 \\
(25.596)\end{array}$ & 0.84 & 0.70 & 0.53 & 0.00 & 0.85 \\
\hline $\mathrm{RI}$ & $\begin{array}{r}-0.540 \\
(0.206)\end{array}$ & $\begin{array}{r}-0.041 \\
(0.651)\end{array}$ & $\begin{array}{r}0.184 \\
(0.174)\end{array}$ & 6.59 & 3.06 & 1.26 & 0.00 & 0.20 \\
\hline $\mathrm{SC}$ & $\begin{array}{r}-0.071 \\
(0.037)\end{array}$ & $\begin{array}{r}-4.466 \\
(3.967)\end{array}$ & $\begin{array}{r}1.122 \\
(1.256)\end{array}$ & 0.27 & 0.32 & 0.04 & 0.00 & 0.89 \\
\hline SD & $\begin{array}{r}-0.213 \\
(0.126)\end{array}$ & $\begin{array}{r}-1.649 \\
(1.378)\end{array}$ & $\begin{array}{r}1.570 \\
(0.661)\end{array}$ & 0.98 & 0.24 & 0.25 & 0.00 & 0.61 \\
\hline TX & $\begin{array}{r}-0.170 \\
(0.174)\end{array}$ & $\begin{array}{r}0.608 \\
(1.334)\end{array}$ & $\begin{array}{r}-0.223 \\
(0.725)\end{array}$ & 0.00 & 4.19 & 0.66 & 0.00 & 0.10 \\
\hline UT & $\begin{array}{r}-0.056 \\
(0.141)\end{array}$ & $\begin{array}{r}0.723 \\
(4.850)\end{array}$ & $\begin{array}{r}-1.086 \\
(2.987)\end{array}$ & 0.00 & 0.25 & 15.72 & 0.00 & 0.31 \\
\hline VT & $\begin{array}{r}-0.084 \\
(0.099)\end{array}$ & $\begin{array}{r}0.606 \\
(2.247)\end{array}$ & $\begin{array}{r}-0.808 \\
(1.864)\end{array}$ & 0.02 & 4.56 & 0.23 & 0.00 & 0.55 \\
\hline VA & $\begin{array}{r}-0.047 \\
(0.085)\end{array}$ & $\begin{array}{r}3.103 \\
(4.186)\end{array}$ & $\begin{array}{r}-1.743 \\
(3.367)\end{array}$ & 1.91 & 4.85 & 1.17 & 0.00 & 0.81 \\
\hline WA & $\begin{array}{r}-0.274 \\
(0.172)\end{array}$ & $\begin{array}{r}0.826 \\
(0.626)\end{array}$ & $\begin{array}{r}0.333 \\
(0.244)\end{array}$ & 0.11 & 1.12 & 1.09 & 0.00 & 0.22 \\
\hline WV & $\begin{array}{r}-0.115 \\
(0.112)\end{array}$ & $\begin{array}{r}3.167 \\
(3.536)\end{array}$ & $\begin{array}{r}-0.597 \\
(0.999)\end{array}$ & 0.01 & 0.82 & 1.78 & 0.00 & 0.68 \\
\hline WI & $\begin{array}{r}-0.041 \\
(0.050)\end{array}$ & $\begin{array}{r}6.637 \\
(6.752)\end{array}$ & $\begin{array}{r}-3.088 \\
(3.521)\end{array}$ & 2.52 & 1.06 & 1.11 & 0.00 & 0.84 \\
\hline WY & $\begin{array}{r}-0.018 \\
(0.127)\end{array}$ & $\begin{array}{r}-1.731 \\
(19.070)\end{array}$ & $\begin{array}{r}-3.423 \\
(24.564)\end{array}$ & 0.04 & 0.00 & 1.06 & 0.00 & 0.65 \\
\hline
\end{tabular}

${ }^{a}$ Standard errors are in parentheses. 
Table 2: Alternative Pooled Estimates for HCE (46 states).

\begin{tabular}{|c|c|c|c|}
\hline Variable & PMG & MG & DFE \\
\hline \multicolumn{4}{|l|}{$\begin{array}{l}\text { A: Long-run Coefficients } \\
\text { Panel A: ARDL }(1,0,0)\end{array}$} \\
\hline Income Elasticity & $\begin{array}{r}0.825^{*} \\
(0.156)\end{array}$ & $\begin{array}{r}0.553 \\
(0.972)\end{array}$ & $\begin{array}{r}0.283 \\
(0.223)\end{array}$ \\
\hline Inflation Effect & $\begin{array}{r}-0.359^{*} \\
(0.059)\end{array}$ & $\begin{array}{r}-0.074 \\
(0.273)\end{array}$ & $\begin{array}{r}-0.151 \\
(0.086)\end{array}$ \\
\hline Speed of Adjustment & $\begin{array}{r}-0.110^{*} \\
(0.013)\end{array}$ & $\begin{array}{r}-0.302^{*} \\
(0.031)\end{array}$ & $\begin{array}{r}-0.102^{*} \\
(0.015)\end{array}$ \\
\hline \multicolumn{4}{|l|}{ Panel B: ARDL $(1,1,1)$} \\
\hline Income Elasticity & $\begin{array}{r}0.820^{*} \\
(0.188)\end{array}$ & $\begin{array}{r}0.408 \\
(0.572)\end{array}$ & $\begin{array}{r}0.476^{*} \\
(0.141)\end{array}$ \\
\hline Inflation Effect & $\begin{array}{r}-0.481^{*} \\
(0.089)\end{array}$ & $\begin{array}{r}-0.036 \\
(0.283)\end{array}$ & $\begin{array}{r}-0.415^{*} \\
(0.083)\end{array}$ \\
\hline Speed of Adjustment & $\begin{array}{l}-0.097^{*} \\
(0.007)\end{array}$ & $\begin{array}{c}-0.254^{*} \\
(0.032)\end{array}$ & $\begin{array}{r}-0.093^{*} \\
(0.009)\end{array}$ \\
\hline \multicolumn{4}{|l|}{ Panel C: ARDL (SBC) } \\
\hline Income Elasticity & $\begin{array}{r}0.852^{*} \\
(0.110)\end{array}$ & $\begin{array}{r}0.349 \\
(0.535)\end{array}$ & \\
\hline Inflation Effect & $\begin{array}{r}-0.479^{*} \\
(0.062)\end{array}$ & $\begin{array}{r}-0.102 \\
(0.234)\end{array}$ & \\
\hline Speed of Adjustment & $\begin{array}{l}-0.138^{*} \\
(0.028)\end{array}$ & $\begin{array}{r}-0.264^{*} \\
(0.035)\end{array}$ & \\
\hline \multicolumn{4}{|l|}{ B: Sort-run Coefficients } \\
\hline Level & $\begin{array}{l}0.118^{*} \\
(0.024)\end{array}$ & & \\
\hline First Difference & $\begin{array}{r}-0.020 \\
(0.012)\end{array}$ & & \\
\hline Inflation Effect & & & \\
\hline Level & $\begin{array}{r}-0.066^{*} \\
(0.014)\end{array}$ & & \\
\hline First Difference & $\begin{array}{l}-0.681^{*} \\
(0.057)\end{array}$ & & \\
\hline Competing Pooled Estimates & DOLS & FMOLS & GMM \\
\hline Income Elasticity & $\begin{array}{r}0.528^{*} \\
(0.069)\end{array}$ & $\begin{array}{r}0.406^{*} \\
(0.062)\end{array}$ & $\begin{array}{r}-0.060 \\
(0.105)\end{array}$ \\
\hline Inflation Effect & $\begin{array}{r}0.022 \\
(0.026)\end{array}$ & $\begin{array}{r}0.095^{*} \\
(0.025)\end{array}$ & $\begin{array}{r}-0.434^{*} \\
(0.089)\end{array}$ \\
\hline
\end{tabular}

${ }^{a}$ Standard errors are in parentheses.

${ }^{b}$ The asterisk indicates that the coefficient is significant at the $5 \%$ level. 
Table 3: Alternative Pooled Estimates for HCE (37 states).

\begin{tabular}{|c|c|c|c|}
\hline Variable & PMG & MG & DFE \\
\hline $\begin{array}{l}\text { A: Long-run Coefficients } \\
\text { Panel A: ARDL }(1,0,0)\end{array}$ & & & \\
\hline Income Elasticity & $\begin{array}{r}0.799^{*} \\
(0.161)\end{array}$ & $\begin{array}{r}0.622 \\
(1.210)\end{array}$ & $\begin{array}{r}0.306 \\
(0.243)\end{array}$ \\
\hline Inflation Effect & $\begin{array}{r}-0.359^{*} \\
(0.060)\end{array}$ & $\begin{array}{r}-0.143 \\
(0.339)\end{array}$ & $\begin{array}{r}-0.221^{*} \\
(0.089)\end{array}$ \\
\hline Speed of Adjustment & $\begin{array}{r}-0.123^{*} \\
(0.013)\end{array}$ & $\begin{array}{r}-0.267^{*} \\
(0.031)\end{array}$ & $\begin{array}{r}-0.098^{*} \\
(0.016)\end{array}$ \\
\hline Panel B: ARDL (1, 1, 1) & & & \\
\hline Income Elasticity & $\begin{array}{l}0.779^{*} \\
(0.194)\end{array}$ & $\begin{array}{r}0.375 \\
(0.706)\end{array}$ & $\begin{array}{r}0.485^{*} \\
(0.147)\end{array}$ \\
\hline Inflation Effect & $\begin{array}{r}-0.466^{*} \\
(0.090)\end{array}$ & $\begin{array}{r}-0.024 \\
(0.346)\end{array}$ & $\begin{array}{l}-0.439^{*} \\
(0.087)\end{array}$ \\
\hline Speed of Adjustment & $\begin{array}{r}-0.106^{*} \\
(0.006)\end{array}$ & $\begin{array}{r}-0.204^{*} \\
(0.029)\end{array}$ & $\begin{array}{r}-0.092^{*} \\
(0.009)\end{array}$ \\
\hline Panel C: ARDL (SBC) & & & \\
\hline Income Elasticity & $\begin{array}{r}0.794^{*} \\
(0.117)\end{array}$ & $\begin{array}{r}0.267 \\
(0.657)\end{array}$ & \\
\hline Inflation Effect & $\begin{array}{r}-0.455^{*} \\
(0.071)\end{array}$ & $\begin{array}{r}-0.083 \\
(0.282)\end{array}$ & \\
\hline Speed of Adjustment & $\begin{array}{r}-0.135^{*} \\
(0.025)\end{array}$ & $\begin{array}{r}-0.218^{*} \\
(0.032)\end{array}$ & \\
\hline $\begin{array}{l}\text { B: Sort-run Coefficients } \\
\text { Income Elasticity }\end{array}$ & & & \\
\hline Level & $\begin{array}{r}0.107^{*} \\
(0.020)\end{array}$ & & \\
\hline First Difference & $\begin{array}{r}-0.020 \\
(0.014)\end{array}$ & & \\
\hline Inflation Effect & & & \\
\hline Level & $\begin{array}{c}-0.061^{*} \\
(0.011)\end{array}$ & & \\
\hline First Difference & $\begin{array}{c}-0.749^{*} \\
(0.059)\end{array}$ & & \\
\hline
\end{tabular}

${ }^{a}$ Standard errors are in parentheses.

${ }^{b}$ The asterisk indicates that the coefficient is significant at the $5 \%$ level . 